\title{
Total Phenol Content and Antioxidant Activity of Okra Seeds from Different Genotypes
}

\author{
Jochebed O. Graham1, Jacob K. Agbenorhevi ${ }^{1, *}$, Fidelis M. Kpodo ${ }^{1,2}$ \\ ${ }^{1}$ Department of Food Science and Technology, Kwame Nkrumah University of Science and Technology, Kumasi, Ghana \\ ${ }^{2}$ Department of Nutrition and Dietetics, University of Health and Allied Sciences, Ho, Ghana \\ *Corresponding author: jkagbenorhevi.cos@knust.edu.gh; jkagbenorhevi@yahoo.com
}

\begin{abstract}
Okra (Abelmoschus spp.) is a staple vegetable in Ghana and several countries world-wide. It has potential for several uses but is mostly under-utilized in Ghana. In this study, the total phenol content and antioxidant activity of five different okra seed genotypes (Asha, Asontem, Agbagoma, Sengevi and Penkruma), subjected to different treatments, were determined. A sensory test was performed to determine the acceptability of tea made with the okra seeds. The total phenol content and free radical scavenging activity of the samples were determined by means of Folin-Ciocalteu method and DPPH assay, respectively. An affective test was used for the sensory analysis. The results indicated that undefatted samples had the highest total phenol content (34.89-39.39 mg GAE/100 g) whereas defatted samples recorded the least (27.83-30.39 mg GAE/100 g). Defatted samples had \% DPPH inhibition in the range of 46.38 to $64.00 \%$ ) whereas that of undefatted samples ranged $34.39-53.00 \%$. However, for the tea infusion of the defatted samples, "Penkruma" had the highest \% DPPH Inhibition 60.42 $13.90 \%$ ) whereas “Agbagoma”, the least (36.94 $\pm 2.81 \%)$. “Agbagoma” and "Sengevi” okra seeds tea infusions had the highest total phenol content (31.56 \pm 2.28 and $31.72 \pm 3.06 \mathrm{mg}$ GAE/100 g, respectively) while "Penkruma" had the least (28.17 $\pm 0.31 \mathrm{mg}$ GAE$/ 100 \mathrm{~g})$. About $40 \%$ of the sensory panellists liked the tea infusion and were willing to purchase if made available on the market. The remaining $60 \%$ however, disliked the infusion because of its taste and stated that they would prefer it with additives such as sweeteners and milk. However, the findings suggest that the okra seed genotypes have considerable amounts of phenols and antioxidant activity and their utilization as tea or in other diets could provide antioxidant benefits.
\end{abstract}

Keywords: Abelmoschus spp., free radical scavenging activity, tea

Cite This Article: Jochebed O. Graham, Jacob K. Agbenorhevi, and Fidelis M. Kpodo, “Total Phenol Content and Antioxidant Activity of Okra Seeds from Different Genotypes.” American Journal of Food and Nutrition, vol. 5, no. 3 (2017): 90-94. doi: 10.12691/ajfn-5-3-2.

\section{Introduction}

Okra (Abelmoschus esculentus) is a vital vegetable that is widely found in most countries worldwide. It is however far more heavily represented in West Africa than any other part of the world [1]. It is also known as lady's finger and is a flowering plant that belongs to the mallow (Malvaceae) family. It has been named "the perfect villager's vegetable" in the African context because of its robust nature, dietary fibres and distinct seed protein [2]. The okra fruit/pod is a greenish capsule that measures up to about $10-25 \mathrm{~cm}$ long, $1.5-3 \mathrm{~cm}$ diameter, slightly curved, tapers to a blunt point, a six-chambered pod of fibrous texture, containing numerous seeds [3]. Okra is widely consumed in tropical, subtropical and warm temperate countries. It is easy to grow and is suitable for regions with moderate rainfall. The maturity of okra differs with the cultivar and ranges between 60-180 days. Okra is generally considered a minor crop to which until recently, no attention has been paid to its improvement. Okra has significant nutritional value and contains about $85 \%$ water, a small and varying amount of fat and protein, a fair portion of carbohydrates present as cellulose and starch as well as sugar in small quantities [4]. Majority of the okra protein and fat is accumulated in the kernel while the seed coat/hull is concentrated with fibre. It also provides minerals and vitamins (Vitamins A and C) to the body; Potassium, Sodium, Magnesium and Calcium being the principal elements with traces of Iron, Zinc, Manganese and Nickel also present [5,6]. Okra is a multipurpose crop due to the varied use of its leaves, buds, flowers, pods, stems and seeds [7]. The high carbohydrate content of the okra pod propagates its use as a mucilaginous food additive against gastric irritative and inflammative diseases. The anti-adhesive quality of okra has also been explained with the fact that it has a combination of glycoproteins and highly acidic sugar compounds that make up a complex three-dimensional structure $[3,8]$. Okra is used in traditional medication in diverse cultures. In some cultures, it is used as an edible infusion and in different preparation for diuretic effect [9]. The whole okra plant is edible and has various food, non-food and medical applications, however, according to Adelakun et al. [10], the seed is the nutritionally richest part of the okra. The seeds of okra are good sources of oil and protein. Okra seeds, like soyabean, is a rich protein source and has 
a high lysine level and is therefore used as a supplement to cereal-based diet that have lysine as a limiting amino acid [11]. The rare combination of seed protein rich and balanced in tryptophan, lysine and sulphur-containing amino acids (unlike cereal proteins) makes okra seeds exceptionally useful in diet. They can be used for oil production or as a substitute for non-caffeinated coffee/tea. The oil obtained from okra seeds is rich in palmitic, oleic and linoleic acids $[12,13]$. The seed powder is also used as an aluminium salt substitute in water purification [14]. Okra seeds serve as an alternative source of protein, fibre, fat and sugar $[10,15,16]$. The seeds are used as an antispasmodic, cordial and a stimulant [17]. Okra may be used in its fresh or processed state (mainly dried) and preserved for later use. Due to its high moisture content and respiratory activities, okra is very perishable and hence, taking it through some primary processing to limit/stop enzymatic and microbial activities may be necessary for preservation. Presently in Nigeria especially, okra is limited to re- generational purposes, hence, farmers only plant them for the seedlings and the large quantities which are deemed as "unfit" for seedling purposes are discarded, facilitating postharvest losses.

Okra is a good contributor to antioxidant status as well as a promising chemo-preventive agent. Phenolic compounds have recently gained a lot of interest among other antioxidants. Pods and seeds of okra are rich phenolic sources with important biological properties like quatering derivatives, catechin oligomers and hydroxy cinnamic derivatives [6]. Okra seed, however, according to Arapitsas [6] is specifically composed mainly of oligomeric catechins and flavonol derivatives, suggesting that it might possess some antioxidant properties.

Different studies have been reported concerning the chemical composition, volatile fraction/components and quantitative analysis of the total dietary fibre, protein, fat, mineral, ash and carbohydrate of okra. Projects where okra polysaccharides are being extracted from okra pods have been taken up. However, there is no use for the seeds of these okra pods and also, limited information is known concerning the polyphenolic, total phenolic and antioxidant activities of okra, especially the seeds. The objective of this work is to determine the total phenol content and antioxidant activity of the different okra seed genotypes and to find an alternative use for okra seeds in the preparation of tea infusions.

\section{Material and Methods}

\subsection{Sample Preparation}

The pods of Asontem, Asha and Penkruma okra genotypes were obtained from Techiman, Brong Ahafo region whereas Agbagoma and Sengevi okra genotypes were obtained from the Volta region of Ghana. The seeds were removed from the okra fruit using a knife and stored in a freezer. They were later dried for three days using a solar dryer, roasted at a temperature of $200^{\circ} \mathrm{C}$ for $3 \mathrm{~min}$ and milled using a blender to a particle size of 600 microns. Each of the roasted ground okra genotype seeds were divided into three portions for analysis: the undefatted roasted and ground portion, the defatted roasted and ground portion, and the defatted portion to be used for the infusion.

Defatting: $15 \mathrm{~g}$ of the samples to be defatted was mixed with $225 \mathrm{ml}$ of petroleum ether in conical flasks in a 1:15 ratio. They were placed on the Rietstra rotary shaker for 5 $\mathrm{h}$ at a speed of $105 \mathrm{rpm}$. The petroleum ether and fat portion were filtered off after $5 \mathrm{~h}$ and the residue was dried in the GenLab oven at $70^{\circ} \mathrm{C}$ for $10 \mathrm{~min}$.

Infusion: $0.01 \mathrm{~g}$ of the defatted samples was dissolved in $20 \mathrm{ml}$ of hot water and the infusion was obtained by filtering the mixture with a filter paper. This infusion was used in the analysis.

\subsection{Determination of Total Phenols and Antioxidant Activity}

Folin-Ciocalteu phenol reagent $(2 \mathrm{~N})$, Trolox $\left(\mathrm{C}_{14} \mathrm{H}_{18} \mathrm{O}_{4}\right.$ 97\%), Gallic acid $\left(\mathrm{C}_{6} \mathrm{H}_{2}\left(\mathrm{OH}_{3}\right) \mathrm{COOH}\right)$ and 2,2-diphenyl-1picryhydrazyl (DPPH radical) were purchased from Sigma-Aldrich (Poole, Dorset, UK). All other chemicals used were of analytical grade. The total phenols content was determined by means of Folin-Ciocalteu methods [18]. Similarly the free radical scanvenging activity was determined by DPPH assay as previously described [19].

\subsection{Sensory Analysis}

For the sensory analysis, to every $2 \mathrm{~g}$ of the okra seed sample, $25 \mathrm{ml}$ of hot water was added and filtered to obtain the infusion for tasting. A consumer acceptability test was conducted on the infusion of the "Asontem" sample. A panel of 30 were used to assess the acceptability of the infusion with a 5-point hedonic scale, where 1- dislike extremely; 2- dislike slightly; 3- neither like nor dislike; 4like slightly and 5- like extremely.

\subsection{Statistical Analysis}

Statistical significance tests were performed using SPSS (v.20, IBM SPSS Statistics, US) at $\mathrm{p}<0.05$ by means of one-way analysis of variance (ANOVA) followed by LSD post hoc multiple comparisons.

\section{Results and Discussion}

The main interest of this project is to determine the total phenol content and antioxidant activity of the okra seeds.

\subsection{Total Phenol Content}

The results obtained showed that the samples, irrespective of any treatment/processing, contained a substantial amount of phenols. Table 1 shows the various total phenolic contents of the undefatted, the defatted and the infused samples.

On the average, the undefatted samples recorded the highest total phenol content, which was significantly different from the other samples. The total phenol content of the infused and defatted samples differed slightly with no significant differences. This implies that the untreated/undefatted samples contain more phenols compared to the treated samples which lost some of the 
phenols upon processing/further treatments. In his work on the "Effect of Processing on Antioxidant Activity of Conventional Mango Seed”, Arogba [20], concluded that, processing operations involving defatting, leads to profound loss $(\mathrm{p}<0.05)$ of radical scavenging capability. Also, according to Wojdylo et al. [21] phenols possess strong scavenging ability for free radicals due to their hydroxyl groups and may directly contribute to antioxidant action.

Table 1. Total Phenol Content (mg GAE/100g) of Okra Seed Samples at Concentration of $50 \mu \mathrm{g} / \mathrm{ml}$

\begin{tabular}{|l|c|c|c|}
\hline Sample & Infusion & Undefatted & Defatted \\
\hline Asha & $29.28 \pm 0.86^{\mathrm{a}}$ & $35.78 \pm 2.36^{\mathrm{b}}$ & $28.39 \pm 0.71^{\mathrm{a}}$ \\
\hline Asontem & $29.06 \pm 0.24^{\mathrm{a}}$ & $38.00 \pm 2.36^{\mathrm{b}}$ & $28.28 \pm 0.71^{\mathrm{a}}$ \\
\hline Agbagoma & $31.56 \pm 2.28^{\mathrm{a}}$ & $39.39 \pm 7.46^{\mathrm{b}}$ & $29.78 \pm 1.10^{\mathrm{a}}$ \\
\hline Sengavi & $31.72 \pm 3.06^{\mathrm{a}}$ & $38.61 \pm 2.04^{\mathrm{b}}$ & $30.39 \pm 1.65^{\mathrm{a}}$ \\
\hline Penkruma & $28.17 \pm 0.31^{\mathrm{a}}$ & $34.89 \pm 2.51^{\mathrm{b}}$ & $27.83 \pm 0.08^{\mathrm{a}}$ \\
\hline Coffee & $28.83 \pm 0.31^{\mathrm{a}}$ & $35.39 \pm 1.89^{\mathrm{b}}$ & $28.44 \pm 0.24^{\mathrm{a}}$ \\
\hline
\end{tabular}

Values are mean $\pm S D, n=3$. ${ }^{a-c}$ Values in the same row with different superscript letters are significantly different $(p<0.05)$.

The differences obtained in the results of the infused and defatted samples can be attributed to the differences in solvent effectivity. A work done by Gramza et al. [22] states that, ethanol and methanol are better solvents compared to water. In this work, both defatted and samples were dissolved in methanol while the infusions were prepared using hot water. Hence, processing/treatment as well as solvent effectivity affects the total phenol content within a sample. In addition, during defatting, phenolic fatty acids like those rich in linoleic acid are lost. Oil obtained from okra seeds consist mainly of linoleic acid [12,13,23]. This explains the loss in the total phenol content of the defatted samples since some of the fatty acids removed during defatting contained some phenols.

One major disadvantage of using the Folin-Ciocaleu reagent is that, it is not specific for only phenolic compounds but to other substances that can be oxidized by the reagent [24]. It must therefore be noted that the total phenolic content of the samples reported may be exaggerated.

\subsection{Antioxidant Activity}

The results obtained here also showed that the samples possessed radical scavenging capabilities. Table 2 shows the various \%DPPH Inhibition of the undefatted, the defatted and the infused samples.

Table 2. Antioxidant Activity of okra seed sample at concentration of $500 \mu \mathrm{g} / \mathrm{ml}$

\begin{tabular}{|l|c|c|c|}
\hline Sample & Infusion & Undefatted & Defatted \\
\hline $\begin{array}{l}\text { Standard } \\
\text { (Ascorbic acid) }\end{array}$ & $77.62 \pm 2.65^{\mathrm{a}}$ & $23.14 \pm 1.23^{\mathrm{b}}$ & $73.24 \pm 0.40^{\mathrm{a}}$ \\
\hline Asha & $47.41 \pm 1.40^{\mathrm{a}}$ & $34.39 \pm 3.55^{\mathrm{b}}$ & $54.57 \pm 0.40^{\mathrm{a}}$ \\
\hline Asontem & $58.32 \pm 3.43^{\mathrm{a}}$ & $34.39 \pm 2.32^{\mathrm{b}}$ & $64.00 \pm 0.54^{\mathrm{a}}$ \\
\hline Agbagoma & $36.94 \pm 2.81^{\mathrm{a}}$ & $38.97 \pm 1.70^{\mathrm{ab}}$ & $46.38 \pm 1.48^{\mathrm{b}}$ \\
\hline Sengavi & $47.74 \pm 0.31^{\mathrm{a}}$ & $53.71 \pm 0.93^{\mathrm{ab}}$ & $58.86 \pm 1.62^{\mathrm{b}}$ \\
\hline Penkruma & $60.42 \pm 3.90^{\mathrm{a}}$ & $50.55 \pm 4.17^{\mathrm{b}}$ & $59.62 \pm 1.89^{\mathrm{a}}$ \\
\hline Coffee & $53.25 \pm 1.25^{\mathrm{a}}$ & $46.94 \pm 2.16^{\mathrm{ab}}$ & $60.95 \pm 4.04^{\mathrm{ac}}$ \\
\hline
\end{tabular}

Values are mean $\pm \mathrm{SD}, \mathrm{n}=3$. $^{\mathrm{a}-\mathrm{c}}$ Values in the same row with different superscript letters are significantly different $(p<0.05)$.
A trend different from that observed for the results of the Total Phenol Content were obtained for the \%Inhibition of the samples. The highest \%Inhibition was observed for the defatted samples, which was significantly different from the other two groups of samples. The infused and undefatted samples recorded similar results with no significant differences between them. The differences here can also be attributed to the differences in the effectiveness of the solvents used, as mentioned previously. Also, even though the \%Inhibition of the infused samples were expected to have similar results as the defatted samples since they were prepared using the defatted sample, a reduced \%Inhibition was observed for them. This can be attributed to the processing or further treatment they went through. Okra seeds are rich in non-phenolic antioxidants, especially Vitamins A and C $[5,6]$. In their work, "Effect of drying methods and storage on physiochemical properties of okra”, Eze and Akubor [25] found that, most of the non-phenolic antioxidants (vitamins $\mathrm{A}$ and $\mathrm{C}$ mostly) were heat labile. They also found that the vitamin $\mathrm{C}$ content of their samples decreased and attributed this decrease to the fact that, vitamin $\mathrm{C}$ is water-soluble and may be lost through leaching. Therefore, the drying of the seeds (dehydration) and further dissolving the defatted seed samples with hot water degrades and leaches out these antioxidants and hence, they are not accounted for in the infused samples.

According to Kopjar et al. [26], total phenol content and antioxidant activity determination depend on various factors that include the presence of other compounds which may interfere or may be extracted with the phenolics. The low \%Inhibition values recorded for the undefatted samples is therefore as a result of the presence of other compounds present (in the oil/fat) that interfered with the analysis. The removal of these compounds (fat and other residues) therefore gave the phenols that contribute to \%Inhibition a better exposure to be measured.

\subsection{IC 50 Value $(\mu \mathrm{g} / \mathrm{ml})$}

IC50 value is also known as the half maximal inhibitory concentration or the inhibition concentration at 50\% inhibition. It is a measure of the effectiveness of a substance in inhibiting a specific biological or biochemical function.

The IC50 value is calculated by plotting an $x-y$ linear regression for all the various concentrations prepared. Using the equation of the line,

$$
\begin{gathered}
\mathrm{Y}=\mathrm{ax}+\mathrm{b} \\
\mathrm{IC} 50=\frac{(0.5-b)}{a} .
\end{gathered}
$$

Table 3. IC50 $(\mu \mathrm{g} / \mathrm{ml})$ Values of okra seed samples

\begin{tabular}{|l|c|c|c|}
\hline Sample & Infusion & Undefatted & Defatted \\
\hline $\begin{array}{l}\text { Standard } \\
\text { (Ascorbic acid) }\end{array}$ & 152.71 & 269.500 & 52.63 \\
\hline Asha & 405.67 & 637.00 & 338.33 \\
\hline Asontem & 326.33 & 299.67 & 173.00 \\
\hline Agbagoma & 316.67 & 352.00 & 103.50 \\
\hline Sengavi & 333.67 & 239.75 & 28.71 \\
\hline Penkruma & 201.20 & 401.67 & 74.83 \\
\hline Coffee & 127.80 & 364.00 & 92.83 \\
\hline
\end{tabular}

Values are mean $\pm \mathrm{SD}, \mathrm{n}=3$. 
The IC50 values present further comparison between the \% Inhibition of the various concentrations of the samples. A lower IC50 value means better \% Inhibition.

The IC50 values for the sample infusions ranged from 127.800- $405.667 \mu \mathrm{g} / \mathrm{ml}$ while the standard (Ascorbic acid) had an IC50 value of $152.714 \mu \mathrm{g} / \mathrm{ml}$ (Table 3). That of the undefatted samples ranged between 239.750- 637.000 $\mu \mathrm{g} / \mathrm{ml}$ and the defatted samples had IC50 values ranging from $28.714-338.333 \mu \mathrm{g} / \mathrm{ml}$. A similar trend as seen in the DPPH \%Inhibition results above is observed here also, where the defatted samples have the lowest IC50 values, implying a high radical scavenging power on the DPPH assay while the undefatted samples have the highest IC50 values, implying the lowest radical scavenging power on the DPPH assay.

\subsection{Relationship between Total Phenol Content and Antioxidant Activity}

From this work, "Penkruma" had the highest antioxidant activity value however, it did not have the highest total phenol content value. Also, “Agbagoma” had the lowest antioxidant value but its total phenol content value was relatively higher than that of "Penkruma".

A lot of previous works have reported that, there is a high significant relationship between total phenol content and antioxidant activity. This implies that, phenols contribute significantly to antioxidant activity. However, a work by Harish and Shivanandappa [27] showed that, compounds other than phenols, mostly known as nonphenolic antioxidants (Vitamins A, E, C, beta carotene etc.), also contribute to antioxidant activity. In addition, according to Khomsug et al. [24], high total phenol content values do not always correspond in a linear fashion to a high antioxidant activity and this is because the Folin-Ciocalteu reagent is not specific for just phenolic contents but also to any other substance that can be oxidized by the reagent. This therefore explains the reason for the observed relationship between the total phenol content and antioxidant activity of the okra seed samples.

\subsection{Sensory Analysis}

Figure 1 summarizes the results obtained from the consumer acceptability test conducted on the infusion of the "Asontem" sample.

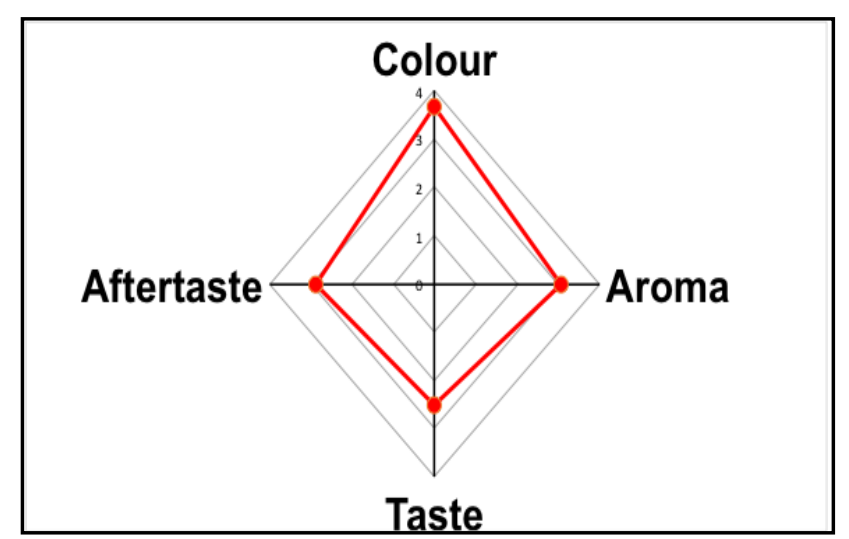

Figure 1. Consumer acceptability scores on a 5-point hedonic scale (Scale: 1-dislike extremely; 2-dislike slightly; 3-neither like nor dislike; 4-like slightly; 5-like extremely)
Most of the sensory attributes of the infusion were neither liked nor disliked by the panelists. On the average however, color $(3.67 \approx 4.00)$ was liked slightly. The other attributes, aroma $(3.07 \approx 3.00)$; taste $(2.53 \approx 3.00)$ and the aftertaste $(2.9 \approx 3.00)$, were averagely neither liked nor disliked by the panelists.

Considering the buying criteria, $40 \%$ of the panelists (12 out of 30) said they would buy the product if it were on the market. However, the remaining 60\% (18 out of 30) said they wouldn't buy the product on the market and the major reason for this was because of the taste and aftertaste.

In order to be able to assess the pure form of the infusion and also to prevent tainting the taste and getting biased results, the infusion was served with no sugar, sweetener or milk. This explains the reason why majority of the panellist admitted that they would not buy the product mainly because of its taste and aftertaste. On the other hand, the minority (40\%) said they would buy the product because it tasted like the tea they were used to without milk and sugar and would be perfect once brewed with these additives. Others said they would buy it because of the claims that okra seeds produced antioxidant benefits and reduced the risks of cardiovascular diseases, neurodegenerative diseases and some cancers [6]. The okra seed infusion (tea) therefore has a potential on the market though it can be incorporated into the diet in other forms.

\section{Conclusion}

The study clearly indicates that the okra seed genotypes have substantial amounts of total phenols and antioxidant activity. These amounts are however affected by processing and treatments. Defatted samples recorded highest \%Inhibition (46.38-64.00\%) while undefatted samples recorded the least (34.39-53.00\%). Undefatted samples recorded highest total phenol content (34.89-39.39mg GAE/100g) while defatted samples recorded the least (27.83-30.39mg GAE/100g). The sensory test showed that most people will accept the product once it is on the market provided it is brewed with sweeteners, sugars and other additives. This implies that, these genotypes could give antioxidant benefits if consumed as tea or any alternative product in the diet.

\section{Acknowledgements}

The authors acknowledge the KNUST Research Fund (KREF) for financial support.

\section{References}

[1] Omonhinmin, C. A., \& Osawaru, M. E. (2005). Morphological characterization of two species of Abelmoschus: Abelmoschus esculentus and Abelmoschus caillei. Genet. Resour. Newsl. 144: 51-55.

[2] National Academies Press, 2006. Lost Crops of Africa Volume II: Vegetables. pp. 287.

[3] Lengsfeld, C., Titgemeyer, F., Faller, G., \& Hensel, A. (2004): Glycosylated compounds from okra inhibit adhesion of Helicobacter pylori to human gastric mucosa. J. Agric. Food Chem. 52: 1495-1503. 
[4] Fellows, P., 2000. Food processing technology: Principles and practice. Woodhead Publishers, London.

[5] Moyin-Jesu, E.I. (2007). Use of plant residues for improving soil fertility pod nutrients root growth and pod weight of okra Abelmoschus esculentum L. Bioresour. Tech. 98: 2057-2064.

[6] Arapitsas, P. (2008): Identification and quantification of polyphenolic compounds from okra seeds and skins. Food Chem. 110: 1041-1045.

[7] Mihretu, Y., Wayessa, G., \& Adugna, D. (2014). Multivariate Analysis among Okra (Abelmoschus esculentus (L.) Moench) Collection in South Western Ethiopia. Journal of Plant Sciences, 9(2): 43-50.

[8] Lengsfeld, C., Faller, G., \& Hensel, A., (2007). Okra polysaccharides inhibit adhesion of Campylobacter jejuni to mucosa isolated from poultry in vitro but not in vivo. Animal Feed Science and Technology, 135(1-2): 113-125.

[9] Maramag, R. P. (2013). Diuretic potential of Capsicum frutescens L., Corchorus oliturius L., and Abelmoschus esculentus L. Asian journal of natural and applied science, 2 (1): 60-69.

[10] Adelakun, O. E., Oyelade, O. J., Ade-Omowaye, B. I., Adeyemi, I. A., Van de Venter, M., \& Koekemoer, T. C. (2009). Influence of pre-treatment on yield chemical and antioxidant properties of a Nigerian okra seed (Abelmoschus esculentus Moench) flour. Food and Chemical Toxicology, 47 (3): 657-661.

[11] Al-Wandawi H (1983): Chemical composition of seeds of two okra cultivm. J. Agric. Food Chem. 31: 1355-1358.

[12] Steyn, N. P., McHiza, Z., Hill, J., Davids, Y. D., Venter, I., Hinrichsen, E., Opperman, M., Rumbelow, J., \& Jacobs, P. (2014). Nutritional contribution of street foods to the diet of people in developing countries: a systematic review. Public Health Nutrition, 17(6): 1363-1367.

[13] Jarret, R. L, Wang, M. L, \& Levy, I. J. (2011). Seed oil and fatty acid content in okra (Abelmoschus esculentus) and related species. Journal of Agricultural Food Chemistry, 59(8): 4019-24.

[14] Calisir, S., Ozcan, M., Haciseferogullari, H., \& Yildiz, M. U. (2005). A study on some physico-chemical properties of Turkey okra (Hibiscus esculenta) seeds. Journal of Food Engineering, 68: 73-78.

[15] Oyelade, O.J., Ade-Omowaye, B.I.O., \& Adeomi, V.F. (2003) Influence of variety on protein, fat contents and some physical characteristics of okra seeds. J. Food Eng., 57: 111-114.
[16] Deters, A.M., Lengsfeld, C., \& Hensel, A. (2005). Oligo- and polysaccharides exhibit a structure-dependent bioactivity on human keratinocytes in vitro. Journal of Ethnopharmacology, 102(3): 391-399.

[17] Lim, T. K., 2012. Edible Medicinal and Non-Medicinal Plants: Vol 3, Fruits, pp. 160. Springer Science+Business Media B.V.

[18] Waterhouse, A. L. (2002). Determination of total phenolic compounds. Current Protocols in Food Analytical Chemistry I1.1.1-I1.1.8.

[19] Ghasemi, K., Ghasemi, Y., \& Ebrahimzadeh, M.A. (2009). Antioxidant activity, phenol and flavonoid contents of 13 Citrus species peels and tissues. Pakistan Journal of Pharmacy and Science, 22 (3): 277-281.

[20] Arogba, S.S., (2015). Effect of Processing on Antioxidant Activity of Conventional Mango (Mangifera indica) Seed. Journal of Environmental Science, Toxicology and Food Technology, 9 (4): 50-55.

[21] Wojdylo, A., Oszmianski, J., \& Czemerys, R. (2007). Antioxidant Activity and Phenolic Compounds in 32 Selected Herbs. Food Chemistry, 105(3): 940-949.

[22] Gramza, A., Khokhar, S., Yoko, S., Gliszczynska-Swiglo, A., Hes, M., \& Korczak, J. (2006). Antioxidant Activity of Tea Extracts in Lipids and Correlation with Polyphenol Content. European Journal of Lipid Science and Technology. 108(4): 351-362.

[23] Sami, R., Lianzhou, J., Yang, L., Ma, Y., \& Jing, J. (2013). Evaluation of Fatty Acid and Amino Acid Compositions in Okra (Abelmoschus esculentus) Grown in Different Geographical Locations. BioMed Research International. 1-6.

[24] Khomsug, P., Thongjaroenbuangam, W., Pakdeenarong, N. Suttajit, M., \& Chantiratikul, P. (2010). Antioxidative Activities and Phenolic Content of Extracts from Okra. Research Journal of Biological Sciences, 5(4): 310-313.

[25] Eze, J.I., \& Akubor, P.I. (2012). Effect of Drying Methods and Storage on the Physiochemical Properties of Okra. Journal of Food Process Technology, 3: 177.

[26] Kopjar, M., Tadić, M., \& Piližota, V. (2015). Phenol Content and Antioxidant Activity of Green, Yellow and Black Tea Leaves. Chemical and Biological Technologies in Agriculture, 2(1): 1-6.

[27] Harish, R., \& Shivanandappa, T., (2006). Antioxidant Activity and Hepatoprotective Potential of Phyllanthus niruri. Food Chemistry, 95(2): 180-185. 